\title{
PENGEMBANGAN PERANGKAT PEMBELAJARAN IPA PENDEKATAN SCIENTIFIC PADA POKOK BAHASAN PENCEMARAN LINGKUNGAN UNTUK MELATIHKAN LIFE SKILLS SISWA SMP DAN MENINGKATKAN HASIL BELAJAR
}

\author{
Ummu Khairiyah $^{1)}$, Tjandrakirana ${ }^{2}$, Wahono Widodo ${ }^{3)}$ \\ ${ }^{1)}$ Mahasiswa Program Pascasarjana, Program Studi Pendidikan Sains, Universitas Negeri Surabaya \\ 2) \& 3)Dosen Pascasarjana Prodi Pendidikan Sains Universitas Negeri Surabaya \\ E-mail:ummukhairiyah09@gmail.com
}

\begin{abstract}
A develop research was done about science learning materials (lesson plans, student's worksheets, student's book, and learning achivement test) Scientific approach to the 4D models to teach life skills and the aim of improving student learning outcomes. This research was trial to 35 of junior high school's students of class VII academic year 2014/2015 with One-group pretest-posttest design. Analysis data is descriptive quantitative-qualitative and the results are Validity of learning material valid (3.50); Practicalitybased on: Readability of worksheets and teaching materials $86 \%$ students interesting and easy to understand; Feasibility of instruction good category (3.5); Students response of positive (97\%); Effectiveness based on: Student activities are student center; student learning achivement increased (N-Gain: 0.75); Ability Life skills (Thinking skills, academic skills, social skills) have been trained and the result is increased. The conclusions of this research that science learning material with base Scientific approach to teach Life skills and and improve the student learning achivement in junior high school.
\end{abstract}

Key word: Scientific Approach, Life Skills.

Abstrak: Telah dilakukan penelitian dengan mengembangkan perangkat pembelajaran (RPP, LKS, Materi Ajar, Tes Hasil Belajar) dengan pendekatan Scientific model 4D yang bertujuan untuk melatihkan Life skills dan meningkatkan hasil belajar siswa SMP. Perangkat pembelajaran diujicoba pada 35 siswa kelas VII semester genap tahun ajaran 2014/ 2015 dengan rancangan uji coba One-Group Pretest-Posttest Design. Analisis data dilakukan secara deskriptif kuantitatif- kualitatif dengan hasil Validitas perangkat kategori valid(3,50), Kepraktisan perangkat yang meliputi: Keterbacaan LKS dan materi ajar siswa 86\% menarik dan mudah dipahami; Keterlaksanaan pembelajaran sangat baik $(3,5)$; Respon siswa positif $(97 \%)$; Keefektifan perangkat pembelajaran yang meliputi: Aktivitas siswa bersifat student centered; Hasil belajar siswa meningkat (N-Gain: 0,75); Kemampuan Life skills (Thinking skills, academic skills, social skills) telah dilatihkan dan hasilnya meningkat. Simpulan penelitian ini, bahwa perangkat pembelajaran IPA dengan pendekatan Scientific layak untuk melatihkan life skills dan meningkatkan hasil belajar siswa SMP.

Kata kunci: Pendekatan Scientific, Life Skills

\section{PENDAHULUAN}

Kurikulum yang dikembangkan pemerintah saat ini adalah kurikulum 2013. Kurikulum 2013 yang dicanangkan oleh pemerintah RI mengacu pada $21^{\text {st }}$ century skills. Hal ini tercermin pada Standar Kompetensi Lulusan (SKL) yang tercantum pada Peraturan Menteri Pendidikan dan Kebudayaan (Permendikbud) Nomor 54 Tahun 2013 tentang Standar Kompetensi Lulusan bahwa kriteria mengenai kualifikasi kemampuan lulusan mencakup sikap, pengetahuan dan keterampilan. Hal tersebut mirip dengan dimensi yang di kemukakan oleh Binkley et al (2012) yang menilai $21^{\text {st }}$ century skills dengan dimensi Knowledge, Skills, Attitude, Value, and Ethics (KSAVE). Jika ditelaah lebih dalam dimensi pengetahuan sama dengan dimensi knowledge, dimensi keterampilan adalah dimensi skills dan sikap adalah dimensi dari attitude, value dan ethics.

Trilling \& Fadel (2009) mendefinisikan $21^{\text {st }}$ century skills yang meliputi: (a) learning and innovation skills, (b) information media and technology skills, (c) carrier and life skills. Berdasarkan definisi tersebut, life skills harus dimiliki siswa untuk mempersiapkan diri dalam menghadapi tuntutan masa depan. Peraturan Menteri Pendidikan dan Kebudayaan (Permendikbud) No. 81 Tahun 2013 menjelaskan bahwa kurikulum harus mampu menjawab tantangan-tantangan tersebut dengan cara mengembangkan kemampuan-kemampuan yang dibutuhkan dalam proses pembelajaran. Atas dasar itu untuk mengajarkan life skills kepada siswa, maka perlu untuk mengintegrasikan life skills dalam proses pembelajaran. 
Life skills merupakan pengembangan diri untuk bertahan hidup, tumbuh, dan berkembang sehingga memiliki kemampuan untuk berkomunikasi dan berhubungan baik secara individu, kelompok, maupun melalui sistem dalam menghadapi situasi tertentu (Hopson dalam Puskur, 2006). Menurut Depdiknas (2007), kecakapan hidup (life skills) merupakan kecakapan yang harus dimiliki seseorang untuk berani menghadapi problem hidup dan kehidupan dengan wajar tanpa merasa tertekan, kemudian secara proaktif dan kreatif mencari serta menemukan solusi sehingga mampu mengatasinya. Adapun pendapat lain mengenai kecakapan hidup yakni kecakapan yang dimiliki seseorang dalam menjalani hidup dan kehidupannya dalam statusnya sebagai makhluk individu dalam konteks alam sekitar (Rudiyanto, 2003).

Life skills pada diri seseorang perlu dilatih, karena manfaat life skills bagi siswa adalah sebagai bekal dalam menghadapi dan memecahkan problem hidup dan kehidupan, baik sebagai pribadi yang mandiri, warga masyarakat, maupun sebagai warga Negara (Tim Broad Based Education, 2002). Economic and social research Council (2005) mengatakan bahwa keberhasilan ekonomi didasarkan pada keterampilan, pengetahuan dan potensi yang inovatif. Selain itu, apabila life skills tidak pernah dilatih nantinya akan menghasilkan lulusan yang tidak bisa mandiri, mudah menyerah, tidak mau berusaha, pasif, tidak percaya diri dengan kemampuan yang dimiliki, tidak mampu memecahkan masalah secara kreatif, tidak bisa bekerjasama, serta memiliki etika yang kurang baik.

Mata pelajaran IPA dikembangkan melalui kemampuan berpikir analitis, induktif, dan deduktif untuk penyelesaian masalah yang berkaitan dengan peristiwa alam sekitar. IPA menyediakan berbagai pengalaman belajar untuk memahami konsep dan proses sains. Pengalaman belajar itu meliputi keterampilan mengamati, mengajukan hipotesis, menggunakan alat dan bahan secara baik dan benar dengan selalu mempertimbangkan keamanan dan keselamatan kerja, mengajukan pertanyaan, menafsirkan data, serta mengkomunikasikan hasil temuan secara lisan atau tertulis, menggali dan memilah informasi faktual yang relevan untuk memecahkan masalah.

Berdasarkan hasil observasi di salah satu SMP di Surabaya, dalam proses pembelajaran IPA masih teacher centered dan cenderung textbook oriented. Tatap muka untuk kegiatan praktikum masih sangat minim, biasanya hanya dilakukan 2 kali dalam satu semester. Selebihnya pembelajaran dilakukan dengan ceramah, padahal banyak materi IPA yang membutuhkan kegiatan praktikum atau melakukan pengamatan. Dapat dikatakan bahwa masih jarang dilakukan kegiatan eksperimen dan praktikum sehingga siswa kurang terampil didalam menyelesaikan masalah, akibatnya kemampuan life skills yang dimiliki siswa kurang.

Salah satu pendekatan pengajaran yang mampu melibatkan siswa berperan aktif adalah pendekatan scientific. Melalui pendekatan scientific selain menjadikan siswa lebih aktif dalam mengkonstruksi pembelajaran dan keterampilan, juga dapat mendorong siswa untuk melakukan penyelidikan guna menemukan fakta-fakta dari suatu fenomena atau kejadian (Kemendikbud, 2013). Pendekatan scientific mampu menyediakan berbagai pengalaman belajar untuk memahami konsep dan proses sains meliputi keterampilan mengamati, mengajukan hipotesis, mengajukan pertanyaan, menggolongkan dan menafsirkan data, mengkomunikasikan hasil data yang diperoleh, menggali dan memilah informasi yang relevan untuk digunakan dalam memecahkan masalah dalam kehidupan sehari-hari yang dekat dengan siswa (Kemendikbud, 2013).

Pada beberapa materi pembelajaran IPA dapat dilakukan dengan menggunakan pendekatan scientific, misalnya materi pencemaran lingkungan. Dalam materi pencemaran lingkungan siswa kemungkinan dapat berperan secara aktif dan terlibat langsung dalam pembelajaran, dikarenakan masalah pencemaran lingkungan merupakan masalah yang kontekstual dan sangat dekat dengan kehidupan siswa, sehingga perlu mendapatkan perhatian yang lebih untuk ditanggulangi oleh semua pihak, dan siswa merupakan anggota masyarakat yang perlu terlibat dalam menanggulangi masalah pencemaran lingkungan.

Sesuai dengan KD 3.9 yakni mendeskripsikan pencemaran dan dampaknya bagi makhluk hidup, siswa akan dihadapkan dengan situasi-situasi yang menuntut untuk berfikir secara kritis, berperan secara aktif dan menuntut untuk bersosialisasi dalam mengatasi pencemaran lingkungan. Sehingga, kemungkinan dengan menggunakan pendekatan scientific dalam proses pembelajaran mampu mengatasi masalah pencemaran lingkungan yang terjadi dalam kehidupan siswa sehari-hari serta secara tidak langsung mengajarkan life skills siswa.

Berdasarkan hasil analisis perangkat pembelajaran berupa buku siswa yang digunakan pada Kurikulum 2013, terdapat beberapa temuan yaitu keterampilanketerampilan proses sains yang harus dikuasai oleh siswa pada tingkat Sekolah Menengah Pertama SMP) seperti memprediksi, menganalisis dan membuat inferensi, tidak dijelaskan secara terperinci pada bagian panduan menggunakan buku pada Buku Siswa. Hal ini berdampak pada kurangnya pemahaman siswa dalam melatihkan keterampilan-keterampilan tersebut, selain itu, pada kegiatan praktikum. Buku Siswa tidak secara konsisten meminta siswa untuk melakukan kegiatan 
yang mengarah pada pelatihan keterampilan proses sains yang telah disebutkan sebelumnya. Keterampilan proses sains dirasa penting dibelajarkan dalam kegiatan pembelajaran, pernyataan tersebut sejalan dengan Nur dalam dalam Adisendjaja (2010), penyajian materi (pengetahuan) harus dikombinasikan dengan pendekatan keterampilan proses.

Lebih lanjut, Adisendjaja dan Romlah, (2007), menyatakan bahwa keterampilan proses sains merupakan sarana mendasar bagi siswa untuk memperoleh pengetahuan atau pemahaman, dan mengembangkan keterampilan berpikirnya. Keterampilan proses sains sangat mendukung peran aktif siswa dalam pembelajaran sehingga dapat melatihkan life skills siswa seperti mencari tahu, menggali informasi, bertanya, dan pembentukan kepercayaan diri siswa melalui kegiatan diskusi di dalam kelas. Berdasarkan latar belakang yang tersebut, maka peneliti mengembangkan perangkat pembelajaran yang berjudul: "Pengembangan perangkat pembelajaran IPA dengan pendekatan scientific pada pokok bahasan pencemaran lingkungan di SMP untuk melatihkan life skills siswa dan meningkatkan hasil belajar".

\section{METODE PENELITIAN}

Penelitian ini merupakan jenis penelitian pengembangan, yaitu mengembangkan perangkat pembelajaran yang mengacu pada model pengembangan perangkat 4D (four $D$ model) yang dimodifikasi sesuai kebutuhan. sebagai berikut:

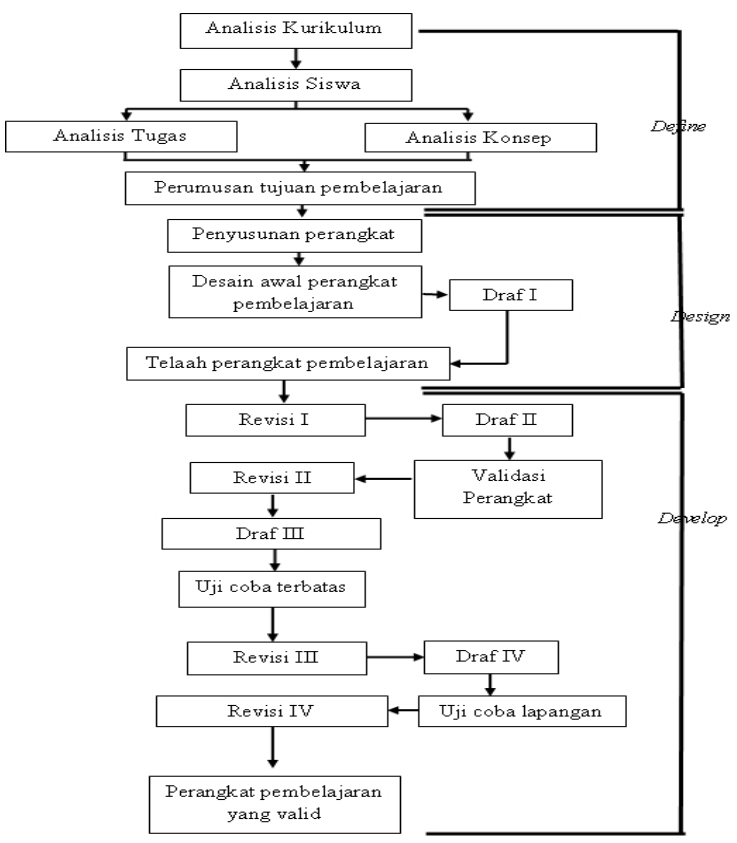

Gambar 1. Diagram Alur Tahap Pengembangan Perangkat(Diadaptasi dari, Thiagarajan, 1974)

Ujicoba penelitian ini dilakukan pada 35 orang siswa kelas VII SMP Kartika IV-1 Surabaya Tahun Pelajaran 2014-2015dengan menggunakan rancangan penelitian One-Group Pretest-Postest Design, karena penelitian ini hanya menggunakan satu kelompok saja tanpa adanya kelompok pembanding. Instrumen penelitian ini kemudian di validasi oleh tiga pakar pendidikan. Teknik pengambilan data pada penelitian ini adalah dengan observasi, tes dan angket. Materi yang dikembangkan adalah materi pencemaran lingkungan.

\section{HASIL DAN PEMBAHASAN}

Berdasarkan hasil uji coba perangkat pembelajaran yang telah dikembangkan dan diimplementasikan di SMP Kartika IV-1 Surabaya berupa, validasi perangkat, keterbacaan perangkat, keterlaksanaan pembelajaran, aktivitas siswa, hasil belajar siswa, respon siswa, dan kemampuan life skills siswa akan ditampilakan berikut ini:

\section{A. Validitas Perangkat Pembalajaran}

Validasi perangkat pembelajaran yang dikembangkan diperoleh hasil sebagai berikut: validitas RPP pada setiap aspek yang dinilai diperoleh validitas RPP yang digunakan memenuhi dua kategori yaitu baik dan sangat baik. Validitas materi ajar yang digunakan memenuhi kategori valid. Validitas LKS yang meliputi aspek petunjuk, kebenaran isi, kemampuan life skills siswa dengan pendekatan scientific, prosedur, dan pertanyaan berkategori valid. Hasil validitas tes hasil belajar pada aspek validitas isi serta bahasa dan penulisan soal berkategori valid dan sangat valid.

\section{B. Kepraktisan Perangkat Pembelajaran}

Kepraktisan perangkat pembelajaran dalam penelitian ini ditinjau dari keterlaksanaan pembelajaran, keterbacaan materi ajar dan LKS, dan respon siswa.

\section{Keterbacaan Perangkat Pembelajaran}

Keterbacaan materi ajar dan LKS secara umum dinyatakan baik. Hasil ini menunjukkan bahwa tingkat membaca siswa berada pada tingkat instruksional atau materi yang termuat dalam buku ajar sesuai dengan pembelajaran, sedangkan Finn (1993) dalam Kisyani (2007), Asem (2013), menyatakan bahwa keterbacaan (readability) merupakan ukuran tentang sesuai atau tidaknya bahan bacaan (buku ajar) bagi pembaca (siswa), dan berdasarkan pernyatan Finn (1993) dalam Kisyani (2007), Asem (2013) tersebut, dapat dinyatakan bahwa materi yang termuat dalam buku ajar yang dikembangkan cocok atau sesuai dengan siswa. Tingkat keterbacaan buku ajar yang dikembangkan ini, berkaitan erat dengan aspek atau teknik penyajian dan bahasa yang digunakan. sehingga dalam penyusunan buku ajar sebagai sumber belajar harus menggunakan bahasa yang tepat, jelas, mudah dipahami, dan komunikatif, karena dengan pemilihan dan penggunaan bahasa yang demikian dapat membantu mempercepat penyampaian dan penguasaan materi ajar oleh siswa. 
BSNP (2007), menyampaikan bahwa kesanggupan seseorang untuk menerima dan mengolah informasi secara optimal dipengaruhi oleh tingkat perkembangan psikososial, sehingga dalam menyusun suatu buku ajar, harus memperhatikan kematangan kognitif dan sosial emosional pembaca (siswa) yang menjadi sasaran buku pembelajaran. Lebih lanjut lagi BSNP (2007), menerangkan bahwa belajar secara bermakna akan mudah terjadi apabila siswa terlibat aktif dalam proses belajar, sehingga dalam penyusunan buku ajar hendaknya menyajikan kegiatan yang dilakukan siswa untuk mempelajari materi yang termuat dalam buku ajar, memuat contoh-contoh yang dekat dengan kehidupan sehari-hari, yang merangsang siswa untuk mencoba atau mengaplikasikan pengetahuan yang diperolehnya, agar siswa memiliki peluang untuk menjadi kreatif dan inovatif. Melalui penyajian seperti ini, siswa akan memperoleh pemahaman yang baik mengenai materi yang termuat dalam buku ajar, dan akan terbentuk transfer of learning, dari segala sesuatu yang dipelajari dari buku ke dalam kehidupan nyata sehari-hari.

\section{Keterlaksanaan Pebelajaran}

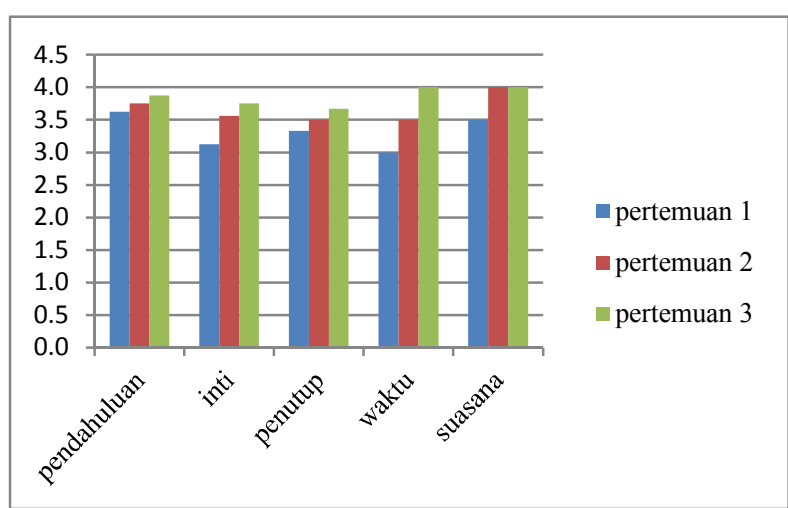

Gambar 2. Diagram Hasil Pengamatan Keterlaksanaan Pembelajaran

Kepraktisan perangkat yang dikembangkan terlihat pada keterlaksanaan pembelajaran yang secara keseluruhan setiap aspek kegiatan pembelajaran terlaksana dengan baik. Aspek-aspek pada kegiatan pendahuluan pada umumnya terlaksana cukup baik pada pertemuan pertama, tetapi pada pertemuan kedua dan ketiga kegiatan pendahuluan berlangsung lebih lancar dan memperoleh penilaian dengan kriteria sangat baik. Tim pengembang MKDP UPI (2011) mengungkapkan bahwa apabila tahap pendahuluan dilakukan dengan baik sesuai karakteristik kebutuhan, materi, metode, lingkungan, serta kemampuan guru maka diasumsikan hasil belajar akan lebih optimal. Sejalan dengan itu Spronken-Smith (2008) mengungkapkan bahwa strategi pembuka pelajaran yang relevan dengan materi yang diajarkan adalah hal yang harus dikuasai oleh guru karena akan mempermudah peralihan yang akan dilakukan terhadap aktivitas belajar utama yang telah disiapkan.

Kegiatan selanjutnya yaitu kegiatan inti. Secara umum pada kegiatan inti siswa lebih mendominasi kegiatan pembelajaran. Kegiatan ini berlandaskan pada teori Vigotsky dalam Slavin (2011) yang mengemukakan bahwa siswa belajar melalui interaksi dengan orang lain yang lebih mampu. Metode ini tidak hanya membuat hasil belajar terbuka untuk seluruh siswa tetapi juga membuat proses berfikir siswa lain terbuka untuk seluruh siswa. Keterlaksanaan RPP untuk pertemuan pertama dirancang dengan memperbanyak bimbingan bagi siswa. Bimbingan yang diberikan oleh guru merupakan scaffolding yaitu memberikan sejumlah besar bantuan kepada siswa selama tahaptahap awal pembelajaran sampai akhirnya siswa tersebut mampu mengambil alih tanggung jawab yang semakin besar segera setelah dia dapat melakukannya (Slavin, 2011).

Tahap akhir dari kegiatan inti yakni presentasi. Kegiatan presentasi merupakan kegiatan penting yang dapat melatih social skills dalam hal keterampilan komunikasi siswa. Sesuai dengan penelitian Yusuf, et al (2012) bahwa untuk meyakinkan keefektifan keterampilan komunikasi siswa, guru harus menggunakan beberapa aktivitas seperti diskusi dan presentasi lisan. Kegiatan presentasi memungkinkan terjadinya proses diskusi antara siswa dengan siswa maupun siswa dengan guru. Hal ini sesuai dengan teori belajar sosial oleh Vygotsky dalam Slavin (2011) tentang zona perkembangan terdekat yang menyatakan jika siswa berinteraksi dengan orang lain yang lebih tahu baik guru maupun temannya, maka siswa akan dapat mencapai tingkat perkembangan sedikit di atas kemampuan aktualnya. Carla, et al (2012) dalam penelitiannya juga menyatakan bahwa pentingnya melatihkan kecakapan sosial dalam pembelajaran dapat membantu siswa dalam meningkatkan keterampilan komunikasi dan interaksi sosial secara baik.

3. Respon Siswa

Hasil penelitian menunjukkan siswa merespon positif terhadap perangkat pembelajaran. Kondisi inilah yang membuat siswa antusias dalam mengikuti kegiatan pembelajaran, karena pada dasarnya kegiatan belajar siswa dipengaruhi oleh motivasi Motivasi belajar siswa dapat dilihat dari respon siswa yang baik dari segi minat dan perhatian siswa terhadap pelajaran, semangat siswa untuk melakukan tugas-tugas belajarnya, reaksi yang ditunjukkan siswa terhadap stimulus yang diberikan guru, rasa senang dan puas terhadap tugas yang telah diberikan. Rasa ingin tahu menurut Piaget dalam Ibrahim (2005) akan memotivasi siswa untuk terlibat aktif dalam pembelajaran serta membangun pemahaman siswa. 
Siswa yang memiliki motivasi yang tinggi untuk belajar, akan bersungguh-sungguh dalam mempelajari sesuatu. Menurut Subiyanto (1988) siswa akan cenderung malas mempelajari/ mengerjakan sesuatu apabila disuruh, tetapi mereka akan bersemangat melakukan sesuatu jika sesuatu tersebut muncul dari dirinya sendiri. Jadi, melalui motivasi yang tinggi tersebut akan mendorong rasa ingin tahu siswa sehingga siswa akan aktif dan terlibat selama proses pembelajaran

\section{Kefektifan Perangkat Pembelajaran}

Keefektifan perangkat pembelajaran yang dikembangkan ditinjau dari aktivitas siswa selama proses pembelajaran, hasil tes keterampilan proses sains siswa, dan hasil belajar kognitif siswa.

\section{Aktivitas Siswa}

Hasil pengamatan aktivitas siswa selama proses pembelajaran pada pertemuan 1 dan 2 menunjukkan aktivitas tertinggi yang dilakukan siswa adalah melakukan pengamatan/ percobaan. Hal ini membuktikan bahwa siswa antusias melakukan pembelajaran dengan pendekatan scientific yang memberi kesempatan luas untuk menganalisis berbagai fenomena alam yang terjadi di sekitar.

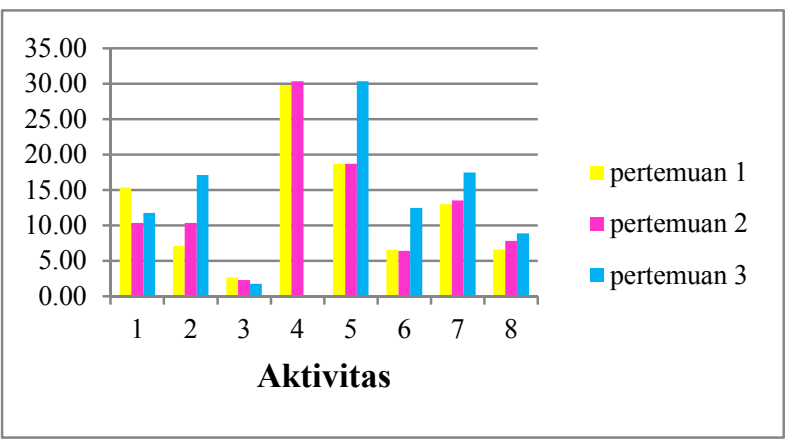

Gambar 3. Diagram Aktivitas Siswa

Menurut Ciardello dalam Spronken-Smith (2008) menyatakan bahwa siswa akan termotivasi dan bangkit rasa ingin tahunya apabila dihadapkan pada fenomena yang tidak sesuai dengan gambaran yang ada di benaknya, sehingga dengan cepat akan mencari informasi yang dapat membantu mereka mengatasi rasa ingin tahunya (curiousity) terhadap permasalahan tersebut.

\section{Hasil Belajar}

Proses pembelajaran dengan menggunakan pendekatan scientific berpengaruh terhadap efektifitas pembelajaran. Hal ini dibuktikan adanya peningkatan hasil belajar siswa berupa tes pengetahuan (kognitif) dan kemampuan life skills.

a. Pengetahuan

Berdasarkan hasil analisis pre test dan post test untuk hasil belajar pengetahuan, telah terjadi peningkatan yang signifikan antara pengetahuan siswa sebelum dan sesudah penerapan pembelajaran dengan pendekatan scientific. Ketuntasan belajar siswa mencerminkan peningkatan tes pemahaman konsep siswa. Meningkatnya pemahaman konsep siswa tersebut tentunya berkaitan dengan aktivitas siswa selama proses pembelajaran berlangsung, khususnya pada aktivitas pengamatan/ percobaan. Dalam aktivitas tersebut, siswa menemukan sendiri pengetahuan baru dengan bimbingan guru.

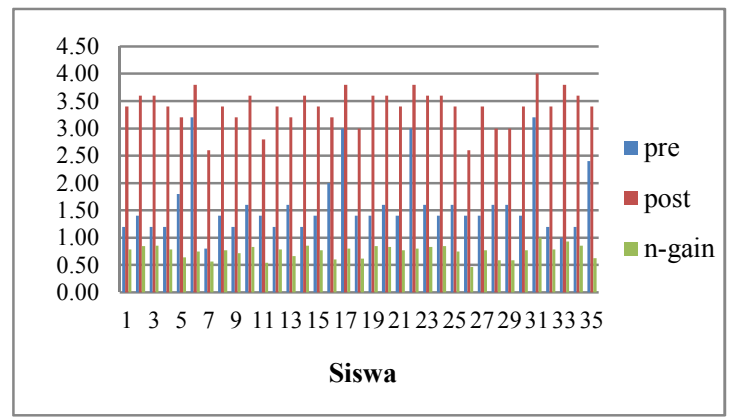

Gambar 4. diagram tes hasil belajar (pengetahuan)

Hasil perhitungan $n$-gain masing -masing siswa juga mendukung meningkatnya hasil belajar siswa aspek pengetahuan. Setiap siswa memiliki skor peningkatan yang tidak sama, hal ini dikarenakan kemampuan kognitif dari setiap individu berbedabeda. Seperti pendapat dari Piaget yang mengasumsikan bahwa peserta didik tumbuh melalui urutan perkembangan intelektual yang sama, tetapi pertumbuhan itu berlangsung dengan kecepatan yang berbeda (Jufri, 2013).

b. Kecakapan Hidup (life skills)

Life skills merupakan sejumlah kecakapan yang perlu dimiliki oleh siswa. Dalam penelitian ini life skills yang diamati adalah thinking skills, academic skills, dan social skills

1) Thinking Skills

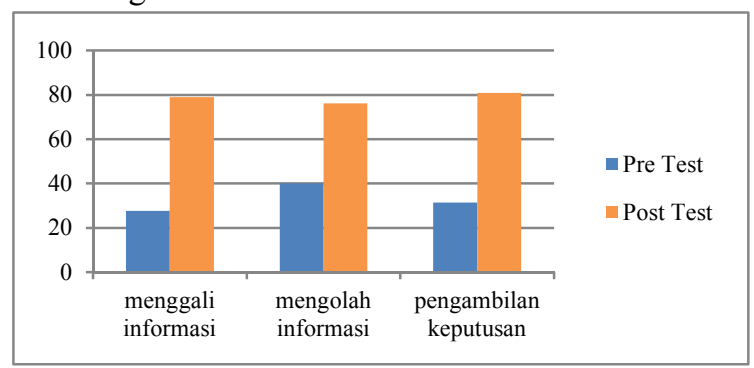

Gambar 5. Diagram kemampuan thinking skills

Hasil analisis keterampilan thinking skills siswa menunjukkan bahwa kompetnsi tertinggi pada keterampilan thinking skills yakni menggali/ mengumpulkan informasi. Hal tersebut dikarenakan kompetensi ini telah dilatihkan dari tahap awal pembelajaran. Sejalan dengan Permendikbud Nomor 81a Tahun 2013 bahwa aktivitas mengumpulkan informasi dilakukan melalui eksperimen, membaca sumber lain selain 
buku teks, mengamati objek/ kejadian/ aktivita wawancara dengan nara sumber dan sebagainya. Sehingga dari kompetensi menggali informasi diharapkan dapat mengembangkan sikap teliti, jujur, sopan, menghargai pendapat orang lain, kemampuan berkomunikasi, menerapkan kemampuan mengumpulkan informasi melalui berbagai cara yang dipelajari, mengembangkan kebiasaan belajar dan belajar sepanjang hayat.

2) Academic Skills

Menurut Samani (2002) academic skills dibutuhkan manusia untuk menjalankan peran manusia sebagai bagian dari lingkungan. Manusia sebagai khalifah di muka bumi dan diamanahi oleh Sang Pencipta untuk memelihara dan memanfaatkan alam lingkungan, demi kemaslahatan untuk manusia. Akhir-akhir ini kerusakan-kerusakan lingkungan sering terjadi di mana-mana. Hal ini dikarenakan oleh ulah manusia yang kurang bertanggung jawab dan kurangnya kesadaran akan pentingnya menjaga lingkungan. Gambaran tersebut menunjukkan bahwa untuk dapat memelihara dan memanfaatkan lingkungan alam dengan arif dan kreatif, diperlukan kecakapan akademik yang terkait dalam bidang itu (academic skills) (Samani, 2002)

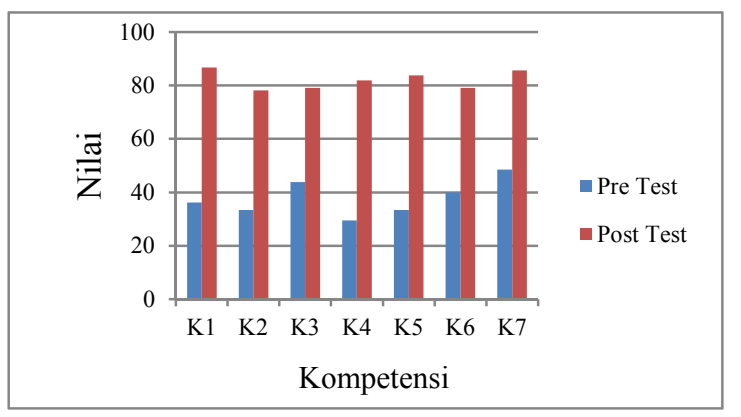

Gambar 6. Diagram kemampuan academic skills

Keterampilan academic skills yang dinilai meliputi K1) merumuskan masalah, K2) merumuskan hipotesis, K3) menentukan variabel, K4) membuat rancangan percobaan, K5) menyajikan data dalam tabel, K6) menganalisis data, dan K7) membuat kesimpulan. Kemampuan tertinggi yang diperoleh siswa yakni merumuskan masalah, hal ini dikarenakan fenomena yang pada LKS sudah menggambarkan tujuan dari LKS yang ingin dicapai sehingga siswa lebih mudah dalam merumuskan masalah.

3) Social Skills

Penilaian keterampilan social skills diperoleh melalui hasil pengamatan selama 3 kali pertemuan. Menurut Samani (2002), bahwa keberhasilan seseorang tidak ditentukan oleh kemampuan kognitifnya atau penguasaan materi saja, tetapi lebih ditentukan oleh kecakapan hidup yang dimilikinya, salah satunya yakni kecakapan sosial.

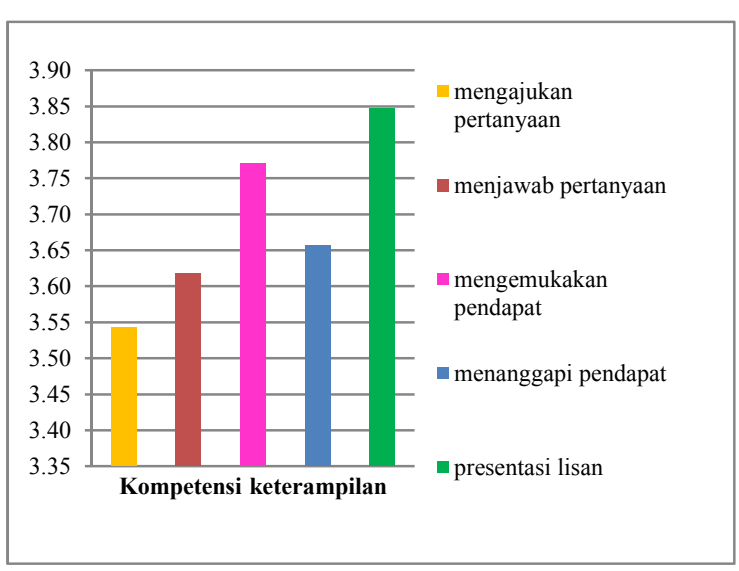

Gambar 7. diagram nilai kemampuan social skills

Hasil analisis keterampilan social skills siswa menunjukkan bahwa kompetensi terendah pada keterampilan social skills yakni mengajukan pertanyaan. Rendahnya kemauan siswa untuk bertanya disebabkan adanya kekhawatiran akan dianggap bodoh apabila terlalu sering bertanya. Perasaan khawatir tidak diterima oleh teman dapat membawa masalah emosi yang serius karena pada remaja kebutuhan untuk diterima di kelompoknya sangatlah penting (Hamalik, 2008).

Berdasarkan penjelasan yang telah diuraikan, dapat disimpulkan bahwa pembelajaran dengan pendekatan scientific dapat meningkatkan pemahaman konsep siswa. Hal ini didukung oleh penelitian Machin (2014) yang menyatakan bahwa pembelajaran dengan pendekatan scientific berpengaruh positif terhadap hasil belajar kognitif, afektif dan psikomotor. Menurut Fauziah, R. et al (2013) menyatakan bahwa pendekatan scientific mengajak siswa langsung dalam menginferensi masalah yang ada, sehingga siswa dapat mengeksplorasi rasa ingin tahunya dengan mencari tahu sendiri melalui kegiatan nyata, jadi informasi, konsep ataupun teori yang diperoleh menjadi lebih bermakna bagi siswa. Pengalaman ini akan mendorong siswa untuk menghadapi ketidakpahaman mereka tentang fenomena dan menggeser ke arah yang lebih memahami konsep. Roodbari, et al (2013) dalam penelitiannya menyatakan dengan pemberian pelatihan kecakapan hidup dapat bermanfaat bagi siswa, yakni dapat meningkatkan prestasi akademik dan siswa dilaporkan memiliki kecenderungan untuk selalu bersikap optimis.

\section{KESIMPULAN}

\section{A. Simpulan}

Atas dasar hasil penelitian dapat disimpulkan bahwa pengembangan perangkat pembelajaran IPA dengan pendekatan scientific, terbukti layak dalam melatihkan kemampuan life skills siswa dan meningkatkan hasil belajar siswa SMP. 


\section{B. Saran}

Setelah dilaksanakan penelitian ini, maka disarankan dalam mengajar IPA dengan pendekatan scientific harus memperhatikan persiapan dan waktu pelaksanaan pembelajaran, supaya proses pembelajaran dapat berlangsung dengan baik.

\section{DAFTAR PUSTAKA}

Adisendjaja dan Romlah, (2007). Analisis Buku Ajar Sains Berdasarkan Literasi Ilmiah Sebagai Dasar untuk Memilih Buku Ajar Sains (Biologi). Jurnal Pendidikan Biologi FPMIPA Universitas Pendidikan Indonesia.

Adisendjaja, (2010). Analisis Buku Ajar Biologi SMA Kelas X di Kota Bandung Berdasarkan Literasi Sains. Jurnal Pendidikan Biologi FPMIPA Universitas Pendidikan Indonesia.

Asem, (2013). Evaluation of Textual Readability: An Analysis Of Its Varying Approaches. International Journal of Research in Humanities, Arts and Literature (IMPACT: IJRHAL), Vol. 1, Issue 4, Sep 2013, 7-12.

Badan Standar Nasional Pendidikan (BSNP). 2006. Panduan Penyusunan KTSP Jenjang Pendidikan Dasar dan Menengah.Jakarta : BNSP

Binkley, Marilyn. (2012). Defining Twenty-First Century skills. London: Springer

Carla, Vidooni., Ulman., and Jerome D. (2012). The fair play game: promoting social skills in physical education. A journal for physical and sport education. V25 n3 p26-30. ISSN 0892 4562

Depdiknas. (2007). Panduan Pengembangan Pembelajaran IPA Terpadu. Jakarta: Puskur, Balitbang Depdiknas

Fauziah, R. Ade Gafar, Dadang Lukman. (2013). Pembelajaran Saintifik Elektronika Dasar Berorientasi Pembelajaran Berbasis Masalah. Invotec, Volume IX, No.2 Agustus 2013 : 165 178

Hamalik, O. (2008). Proses Belajar Mengajar. Jakarta: Bumi Antariksa

Ibrahim, Muslimin. (2005). Pembelejaran berdasarkan masalah; latar belakang, konsep dasar dan contoh implementasinya . Surabaya: Unesa University Press.

Jufri, Wahab. (2013). Belajar dan pembelejaran sains. Bandung: Pustaka Reka Cipta.

Kemendikbud. (2013). Pendekatan Scientific dalam kurikulum 2013. Jakarta: Kementrian Pendidikan dan Kebudayaan

Kisyani, 2007. Membaca 2. Jakarta: Unipersitas Terbuka.

Pusat Kurikulum Depdiknas. (2006). Penerapan Model pendidikan Kecakapan Hidup. Jakarta: Balitbang Depdiknas

Rudiyanto, R. (2003). Kurikulum Berbasis Kompetensi (KBK) Berpendekatan Kon tekstual dan Kecakapan Hidup. Jurnal Pendidikan dan Pengajaran IKIP Negeri Singaraja 36: 60-73.

Samani, M. (2002). Menggagas Pendidikan Bermakna Integrasi Life Skills-KBK-CTL-MBS. Surabaya:SIC.

Slavin, Robert E. (2011). Psikologi Pendidikan (Teori dan Praktik) Jilid 2. Jakarta: PT. Indeks

Spronken-Smith, R. (2008). Experiencing the Process of Knowledge Creation: The Nature and Use of Inquiry-Based Learning in Higher Education. Journal of Research. New Zealand: University of Otago.pp.12-15

Subiyanto. (1988). Pendidikan ilmu pengetahuan alam. Jakarta: PPLPTK.

Thiagarajaan, S., Semmel.D.S. \& Semmel,M.I. (1974). Instructional Development for training teacher of Exceptional Children a Sourcebook. Bloomington: Center for Innovation on teaching the Handicaped

Tim Board Based Education. (2002). Konsep Pendidikan Kecakapan Hidup. Jakarta: Depdiknas

Trilling, B and Fadel, C. (2009). 21 ${ }^{\text {st }}$ Century skills: Learning for life in our times. USA: JosseyBass.

Yusuf, F.A and Adeoye, E.A. (2012). Developing critical thinking and communication skills in students: Implications for practice in education. An International Multidisciplinary Journal, Ethiopia. Vol. 6 (1), Serial No. 24, Januari, 2012 ISSN $2070-0083$ 